\title{
INDIGENOUS COUNSELING: KARAKTERISTIK SPIRITUAL DALAM TRADISI ROBO-ROBO PADA MASYARAKAT KECAMATAN SUNGAI KAKAP, KALIMANTAN BARAT
}

\author{
Saripaini $^{\mathrm{a}, 1,{ }^{*},}$ Maemonah ${ }^{\mathrm{b}, 2}$ \\ ${ }^{a}$ UIN Sunan Kalijaga,Yogyakartat, 55281, Indonesia \\ ${ }^{b}$ UIN Sunan Kalijaga, Yogyakarta,, 55281, Indonesia \\ ${ }^{1}$ saripainikuliah@gmail.com *; ${ }^{2}$ maimunah@uin-suka.ac.id
}

ARTICLE INFO

Article history:

Received : 2021-07-06

Revised : 2021-07-29

Accepted : 2021-12-01

Keywords:

indegenous counseling,

values,

spiritual,

robo-robo

Kata kunci:

konseling indegenous,

nilai,

spiritual,

robo-robo

\section{ABSTRACT}

The robo-robo tradition is a traditional ritual carried out by the Sungai Kakap people as an effort to resist danger. This study explored to describe and identify the characteristics of people spirituality in the process of providing assistance through local community traditions. This research was a qualitative research using descriptive method. Data was collected by observing people's life in the field and interviews. The result revealed that: 1) amongst their existence as human, they had an awareness of the need for the God's help. 2) close to nature and living environment. 3) had close relationships amongst people, social values such as the value of togetherness, the value of sharing and respect, and the value of kinship. 4) The relationship with God in the robo-robo tradition was divided into three groups, namely: first, religious people had faith in Allah SWT, and did not want to involve themselves in the robo-robo tradition. Generally, this group considered this custom to be a deviation in religion. Second, they had faith in Allah SWT, were involved in cultural celebrations but did not believe in the belief traditions developed in these celebrations. Third, they had faith in Allah SWT but also they had faith in other supernatural beings (soul / ancestral soul).

\section{ABSTRAK}

Tradisi robo-robo merupakan satu ritual adat yang dilakukan oleh masyarakat Sungai Kakap sebagai upaya menolak bala bahaya. Penelitian ini bertujuan untuk mendeskiripsikan dan mengidentifikasi karakteristik spiritualitas masyarakat dalam proses pemberian bantuan melalui tradisi masyarakat lokal. Penelitian ini merupakan penelitian kualitatif dengan metode deskriptif. Pengumpulan data dilakukan dengan observasi terhadap kehidupan di lapangan dan wawancara. Berdasarkan hasil analisis data yang telah dilakukan, diperoleh gambaran karakteristik spiritualitas masyarakat Sungai Kakap; 1) Di antara eksistensinya sebagai manusia, mereka memiliki kesadaran akan butuhnya pertolongan Sang Penguasa. 2) dekat dengan alam dan lingkungan tempat tinggal. 3) memiliki keeratan hubungan antar sesama, nilai-nilai sosial kemasyarakatan seperti nilai kebersamaan, nilai berbagi dan menghormati, serta nilai kekeluargaan. 4) Hubungan dengan Tuhan dalam tradisi robo-robo terbagi menjadi tiga kelompok, yaitu: pertama, mereka beragama memiliki keyakinan kepada Allah SWT, dan tidak mau melibatkan diri pada tradisi roborobo. Umumnya kelompok ini menganggap hal demikian dianggap penyimpangan dalam beragama. Kedua, Mereka beragama memiliki keyakinan kepada Allah SWT, terlibat dalam perayaan kebudayaan tapi tidak memiliki keyakinan terhadap tradisi kepercayaan yang berkembang di dalam perayaan tersebut. Ketiga, Mereka beragama memilki keyakinan kepada Allah SWT akan tetapi di sisi yang 
beerlainan juga memiliki keyakinan terhadap kegaiban yang lain (makhluk halus/roh leluhur).

\section{Pendahuluan}

Diskusi tentang ketidaksesuaian nilai antara budaya Barat dan non Barat menjadi menjadi pembahasan menarik sekaligus penting dalam aktualisasi keilmuan. Fakta di lapangan menampilkan bahwa konsep keilmuan Barat tidak selalu dapat diaplikasikasikan di negara non-Barat karena ada perbedaan nilai-nilai kemasyarakatan yang dianut (Chong, 2018; Mohamad, Halaliah, \& Abu, 2011; Sipon \& Hj, 2015) Menanggapi dinamika tersebut memicu sarjana di negara non Barat untuk melakukan penelitian lanjutan agar proses konseling dapat dilakukan dengan mempertimbangkan perbedaan budaya dan karakteristik masyarakat setempat (Mohamad dkk., 2011).

Indonesia sebagai negara yang kaya akan keragaman suku, bahasa, budaya dan agama tidak dapat menepikan pengkajian dan pengembangan konseling pribumi (Sarwono, 2018). Keberagaman di Indonesia membuka peluang dalam rekontruksi konseling (Rangka, 2016). Konseling pribumi (indigenous counseling) merupakan bentuk pelayanan konseling yang menjadi solusi terhadap hambatan-hambatan budaya entah dari aspek nilai norma maupun bahasa di masyarakat (Studies dkk., 2020). Diskusi dan pengkajian terkait konseling pribumi di Indonesia telah dilakukan, baik pengkajian terhadap landasan teoritis, pentingnya pelaksanaan konseling pribumi dalam menyelesaikan masalah ataupun penggalian nilai-nilai kearifan lokal dan implementasinya di dalam bimbingan dan konseling.

Arifin mengkaji tentang pelaksanaan konseling indegnous berbasis pesantren. Di mana konseling didasarkan pada hasil integrasi kelilmuan tasawuf, fiqh dan nilainilai kebudayaan yang berkembang di lingkungan setempat sebagai upaya mengubah tingkah laku santri (Arifin, 2013). Wibowo \& Mudaim mengkaji tentang unsur- unsur budaya Lampung dan impilkasi nilainilai kearifan lokal masyarakat Lampung terhadap pelaksanaan konseling lintas budaya (Wibowo, 2018).

Upaya penggalian nilai-nilai kearifan lokal dan implikasinya terhadap konseling telah ditelaah dalam sejumlah penelitian, di antaranya pemikiran Ki Ageng Suryo Mentaram dalam Kawaruh Jiwa (Suryomentaram, Kawruh, Marhamah, \& Murtadlo, 2015) pemikiran Sunan Kudus tentang konsep gusjigang (Mahmud, Kudus, \& Tengah, t.t.) telaah nilai budaya pill pesenggiri (Sari \& Bulantika, 2019) dan nilainilai kearifan lokal dalam tradisi sedekah bumi (Studies dkk., 2020). Berikutnya juga dilakukan pengkajian teoritis terhadap budaya lokal dan impilikasinya terhadap konseling di masyarakat, di antaranya Hidayah menemukan bahwa aturan lokal yang berlaku di dalam satu kelompok masyarakat dapat mengendalikan tindakan masyarakat yang ada di dalamnya (Hidayah, Apriliana, \& Triningtyas, 2017). Sejalan dengan itu Prasasti melalui penelitiannya yang berjudul konseling indegenous dalam masa new normal mengungkapkan bahwa pendekatan konseling pribumi dapat menjadi solusi untuk membantu manusia dalam menghadapi realitas dan permasalahan kehidupan (Prasasti, Tunas, \& Surakarta, 2020)2020). Berdasarkan kajian terhadap nilai-nilai kebudayaan di atas, maka dapat ditarik satu kesimpulan bahwa kearifan lokal yang telah berkembang dan mengakar di dalam ruang sosial masyarakat memiliki potensi untuk diadopsi dalam praktik konseling pribumi. Akan tetapi dari sejumlah penelitian yang telah dilakukan belum ditemukan paparan bagaimana sisi spiritualitas (keyakinan) masyarakat pribumi yang mempengaruhi tindakan preventif ataupun tindakan kuratif dalam menghadapi sebuah problem. Oleh karena itu tulisan ini difokuskan pada aspek spiritualitas yang berembang di dalam ruang masyarakat. 
Fenomena kehidupan masyarakat moderen di era ini belum sepenuhnya terlepas dari pengalaman spirutualitas masyarakat di masa lampau. Berdasarkan hasil wawancara dan observasi terhadap kehidupan masyarakat di di Kecamatan Sungai Kakap menunjukkan bahwa sebagian masyarakat memiliki kepercayaan ketidakharmonisan di dalam rumah tangga, kesusahan dalam perekonomian, sakit, hingga sakit jiwa dapat disebabkan oleh gangguan roh leluhur atau makhluk halus (Wawancara Induk Tuwo, 2021). Keyakinan tersebut akan muncul apabila peristiwa yang dialami masyarakat tidak logis dan terasa datang bertubi-tubi. Dalam situasi demikian masyarakat akan memilih alternatif pengobatan pribumi, yaitu menemui dukun untuk melakukan praktik ritual adat atau menemui tokoh agama untuk mendapatkan petunjuk atau amalan. Sepanjang langkah penyelesaian masalah tersebut solutif dan efektif masyarakat akan memilihnya, sekalipun terkesan kuno.

Sementara itu masyarakat di Kecamatan Sungai Kakap memiliki tradisi yang dilakukan secara berkala, setahun sekali, yakni tradisi robo-robo. Berdasarkan hasil wawancara tradisi robo-robo dapat dipahami sebagai salah bentuk kearifan lokal yang terdapat pada masyarakat di Kecamatan Sungai Kakap dalam upaya pencegahan terjadinya masalah (Wawancara, Baharudin, 2021). Secara definisi robo-robo adalah tradisi tolak bala yang dilakukan setiap hari Rabu terakhir di bulan Safar (Sd, Boyolali, Tengah, Manusia, \& Indonesia, 2016). Hal ini menunjukkan bahwa masyarakat lokal telah memiliki alternatif pencegahan terjadinya masalah yang telah dilakukan secara turun temurun. Dalam tradisi robo-robo digambarkan bahwa penitikberatan upaya pecegahan dilatarbelakangi oleh kayakinan/pengalaman spiritual yang berkembang di dalam kelompok masyarakat.

Konseling sebagai proses pemberian bantuan yang sarat dengan nilai menuntut konselor untuk memiliki sikap, pengetahuan, serta kapasitas keterampilan yang mumpuni, termasuk dalam mengintegrasikan dimensi spiritual dan religi (Imaduddin, 2017). Oleh karena itu sangat penting untuk menguasai bagaimana budaya, nilai dan spiritualitas (keyakinan) membentuk masyarakat untuk diadopsi dalam proses konseling pada masyarakat indigenous.

Sejalan dengan itu diskusi tentang pendekatan spiritualitas dalam konseling di dunia barat saat ini berkembang pesat dan menjadi trend serta perhatian khusus hal, ini didukung oleh sejumlah penelitian yang yang menyatakan bahwa ada pengaruh perilaku keagamaan dan spiritual (keyakinan) pada kesehatan mental dan fisik individu (Konseling, Vol, Issn, \& Issn, 2017). Spiritualitas dan religiusitas merupakan bagian integral dari diri individu yang menjadi ciri kemanusiaan dan menjadi indikator kualitas kesehatan mental individu (Imaduddin, 2017) bahkan di dalam penelitiannya Wahidin menemukan bahwa Spiritualitas memiliki hubungan yang signifikan dengan happiness pada remaja akhir (Counseling, 2017). Sementara itu dalam penelitian lain juga ditemukan ada 113 artikel yang dipilih mengungkapkan bahwa spiritualitas adalah komponen penting dari kualitas hidup dan yang melengkapiperawatan spiritual yang efektif (Willemse, Smeets, Leeuwen, \& Nielen-rosier, 2020). Agama dan spiritualitas dapat sangat bermanfaat bila digunakan di dalam konseling (Konseling dkk., 2017).

Berdasarkan latar belakang budaya di atas, maka peneliti tertarik untuk mengkaji lebih dalam terkait karakteristik spiritualitas dalam tradisi robo-robo pada masyarakat di Kecamatan Sungai Kakap, Kalimantan Barat dan implikasinya terhadap konseling indigenous. Penelitian ini bertujuan untuk mendeskiripsikan dan mengidentifikasi karakteristik spiritualitas masyarakat dalam proses pemberian bantuan melalui tradisi masyarakat lokal.

\section{Tinjauan Pustaka}

Secara definitif konseling indigenous (pribumi) dapat diartikan sebagai proses pemberian bantuan kepada individu dalam menghadapi permasalahan dengan mengadobsi prisnsip, nilai, cara berfikir, kepercayaan, serta pengetahuan lokal yang dimiliki oleh masyarakat setempat. Starategi konseling demikian memang dirancang khusus untuk masyarakat setempat dan menepikan prinsip dari daerah lain (Sarwono, 2018; Suryomentaram dkk., 2015). 
Hal ini dapat menjadi modal dasar untuk memahami cara berfikir dan karakteristik mayarakat setempat dalam menjalankan alternatif penyelesaian masalah. Tradisi lokal menjadi hal penting untuk membaca masyarakat, di mana praktik tradisi telah berlangsung secara turun temurun dapat mengambarkan bagaimana identitas anggota masyarakatnya (Yusriadi, 2015:9).

Tradisi robo-robo sebagai satu bentuk kearifan lokal yang dilakukan sebagai alternatif menolak bala pada dasarnya bertitik tolak pada pengalaman spiritualitas. Sebab, solusi yang dipakai secara turun temurun selalu ada kaitannya dengan pengalaman, sekalipun bentuknya kerap kali samar serta tidak berkaitan secara langsung. Setidaknya, kaitan itu dapat dilihat tindakan yang diambil oleh masyarakat dalam praktik tradisi.

Sementara itu praktik ritual adat/tradisi yang dilakukan oleh masyarakat pribumi untuk mencegah dan mengatasi permasalahan terasa kurang tepat bila dikatakan sebagai proses konseling. Hal ini didasarkan pada definisi oprasional konseling itu sendiri. Prayitno dan Erman Amti merumuskan konseling sebagai sebuah proses konseling dilakukan oleh seorang ahli (konselor) kepada orang yang mengalami masalah (konseli) yang bermuara pada penyelesaian masalah (Lubis, S. A, 2011: 21). Pada dasarnya seorang konselor harus mengerti psikologi dan proses perkembangan mental manusia, memahami terori konseling beserta pendekatan teoritisnya (Geldard \& Geldart, 2015:8). Senada dengan itu secara terpisah dalam Peraturan Mentri Pendidikan dan Kebudayaan RI nomor 111 tahun 2014 mendefinisikan konselor sebagai pendidik profesional yang berkualifikasi akademik minimal Sarjana Pendidikan (S-1) dalam bidang Bimbingan dan Konseling dan telah lulus pendidikan profesi guru Bimbingan dan Konseling/konselor.

Terlepas dari dapat dikatan sebagai proses konseling atau tidak, tradisi robo-robo tetaplah budaya membantu yang telah lama berkembang pada masyarakat lokal di Kecamatan Sungai Kakap. Selanjutnya tradisi dapat dipakai sebagai bahan untuk memahami interpretasi, keyakinan, dan karakteristik masyarakat. Spiritualitas/keyakinan adalah tradisi robo-robo adalah bagian yang tidak dapat dipisahkan. Sehingga pendekatan konseling dapat melihatnya dari aspek spiritual. Karenanya pendekataan keagamaan di dalam proses konseling, klien dapat diberi insight, yakni kesadaran akan adanya hubungan sebab-akibat dalam rangkaian problem-problem yang dihadapi individu untuk selanjutnya dikoneksikan dengan nilainilai keimanan yang diyakini untuk mengatasi kesulitan yang dihadapi (Basit, 2017: 5).

Spiritualitas dan religiusitas merupakan bagian integral dari diri individu yang menjadi ciri kemanusiaan serta indikator kualitas kesehatan mental individu (Imaduddin, 2017). Stoll merumuskan bahwa spiritualitas merupakan konsep dua dimensi, yaitu dimensi vertikal dan dimensi horizontal. Dimensi verikal dapat dipahami sebagai hubungan dengan Tuhan yang menuntun kehidupan. Sementara dimensi horizontal merupakan hubungan individu dengan dirinya sendiri, hubungan dengan orang lain, dan hubungannya dengan lingkungan (Hamid, Achir Yani, 2008: 3).

Oleh karena itu untuk memberikan bantuan kepada masyarakat pribumi, sangat penting bagi konselor untuk memperhatikan kebutuhan spiritual klien yang dapat diperoleh melalui pengidentifikasian karakteristik konselor. Menurut Hamid pengidentifikasin karakteristik spiritualitas dapat dilihatdari empat komponen, yakni: Hubungan dengan diri sendiri. Kekuatan dalam dan self relience, Hubungan dengan alam harmonis. Hubungan dengan orang lain harmonis/suportif: Hubungan dengan ketuhanan. Agamis atau tidak agamis

\section{Metodologi Penelitian}

Penelitian ini menggunakan
pendekatan kualitatif dengan metode
deskriptif. Di mana penelitian akan
menghasilkan data deskriptif menguraikan,
memaparkan dan menerangkan data-data
yang diperoleh di lapangan yang berkenaan
dengan nilai dan spiritualitas (kepercayaan) di
dalam tradisi robo-robo pada masyarakat di
Kecamatan Sungai Kakap, Kalimantan Barat.
Data-data lapangan diperoleh melalui, survei,
wawancara medalam dan observasi terhadap
adat dan kebudayaan robo-robo. Penelitian ini
melibatkan 25 (dua puluh lima) masyarakat
sungai kakap, 1 orang tokoh agama dan 1


orang dukun kampung. Pengumpulan data dilakukan dengan menyebarkan pertanyaan terbuka dan tertutup kepada informan melalui google formulir.

Tradisi robo-robo dipilih untuk dianalisis karena merupakan satu tradisi yang melibatkan dua tokoh sekaligus, yaitu tokoh agama dan tokoh masyarakat sebagai pemimpin ritual adat sesuai dengan tugas masing-masing. Sementara itu tujuan pelaksanaan tradisi juga memiliki kesamaan dengan tujuan konseling, yakni untuk mencegah/mengatasi masalah.

\section{Hasil dan Diskusi}

\section{Gambaran Umum Tradisi Robo-robo}

Wilayah Sungai Kakap merupakan salah satu tempat berkumpulkanya masyarakat Kalimantan Barat pada perayaan robo-robo. Robo-robo diambil dari nama hari, yakni "Rabu" yang menunujukkan bahwa pelaksanaan robo-robo dilakukan pada hari Rabu. Telah menjadi keyakinan turuntemurun bahwa pada bulan Safar akan banyak bala bahaya. Oleh karena itu secara sederhana tradisi robo-robo dapat diartikan sebagai sebuah tradisi pembacaan doa tolak bala yang dilakukan pada hari Rabu terakhir di bulan Safar.

Masyarakat di kecamatan Sungai Kakap merupakan salah satu kelompok masyarakat yang rutin merayakan hari robo-robo sebagai satu perayaan sakral yang diperingati dengan suka cita. Ada pun pokok-pokok adat dan tradisi yang dilakukan masyarakat saat roborobo sebagai proses membantu, yaitu; pembacaan doa selamat tolak bala, mandi air tolak bala/air Safar, dan buang-buang

1. Pembacaan Doa Selamat Tolak Bala

Pembacaan doa selamat tolak bala pada hari robo-robo dilakukan masyarakat di luar rumah, seperti di perkarangan rumah, jalan raya atau pun lapangan terbuka. Umumnya pelaksanaan pembacaan doa di kampung-kampung dilakukan antara pukul 06.00-08.00 pagi. Pembacaan doa dipimpin oleh tokoh agama yang dituakan dan dihadiri oleh masyarakat setempat. Adapun perlengkapan yang di bawa oleh masyarakat di lapangan adalah makanan berupa ketupat, lepat lau beserta lauk pauknya. Prosesi pembacaan doa diakhiri dengan makan bersama.
2. Mandi Air Tolak Bala atau Air Safar Bertepatan di hari Rabu terakhir di bulan Safar masyarat terbiasa mandi air yang telah dibacakan doa tolak bala oleh tokoh agama setempat. Air yang telah dibaca oleh tokoh agama tersebut diyakini dapat menghindarkan badan (diri) dari ancaman bala bahaya. Mandi air tolak bala di anjurkan di sungai. Pada masa lampau masyarakat biasanya akan sengaja turun ke sungai untuk mandi bersama. Akan tetapi seiring perkembangan waktu tradisi mandi air Safar dilakukan di rumah masing-masing. Hal ini dapat dilihat pada masyarakat di Desa Punggur Kecil, Kecamatan Sungai Kakap.

3. Ritual Buang-buang

Di dalam tradisi robo-robo juga dirangkaikan ritual buang-buang. Pelaksanaan ritual dilakukan di Sungai Kakap. Rombongan Kerabat Kesultanan Qadariah Pontianak, Bupati Kubu Raya akan pergi ke tengah laut menggunakan perahu lancang kuning untuk melaksana ritual buang-buang. Sementara itu masyarakat beramai-ramai menyaksikan di pinggir Sungai/area pelaksanaan perayaan.

Ritual buang-buang merupakan tradisi yang dilakukan masyarakat MelayuBugis untuk mengawali acara penting seperti, acara pernikahan, khitanan, menjelang kelahiran anak (Saripaini \& Yusriadi, 2016). Ritual ini bertujuan untuk mendapatkan kelancaran dan keselamatan. Di dalam praktiknya ritual buang-buang dilaksanakan di sungai atau parit, karena ritual ditujukan kepada makhluk halus yang biasa disebut orang aek (orang air). Masyarakat Bugis di Kalimantan Barat umumnya menyakini orang aek sebagai leluhur.

Secara umum praktik ritual dan perlengkapannya dapat digambarkan sebagai berikut; pertama: Minyak bau ditumpahkan ke sungai. Kedua: air berminyak digaris digaris menggunakan pisau dengan bentuk tambah (+) yang bermakna empat penjuru alam, dukun membacakan mantra. Ketiga: menghamburkan beretih dan beras kuning. Keempat: telur ayam kampung, pinang masak, daun sirih dilarungkan ke air. Cincin emas diikat dengan sapu tangan di celupkan ke dalam air. Kelima: 
air diambil menggunakan piring makan. Kemudian air tersebut diusapkan ke wajah dan perut yang melaksanakan ritual atau yang mempunyai hajat (Yusriadi, 2015: 59; Saripaini, 2016:13). Peralatan ritual buang-buang tidak selalu sama, tergantung tujuan, pemimpin ritual. Misalnya di dalam tradisi robo-robo ada ketupat yang turut dilarung ke laut.

\section{Budaya Membantu dalam Tradisi Robo- robo}

Robo-robo merupakan satu bentuk upaya pencegahan terjadinya masalah (menolak bala bahaya) yang dilakukan oleh masyarakat lokal Kecamatan Sungai Kakap. Tradisi ini berangkat dari keyakinan yang berkembang di dalam ruang sosial masyarakat bahwa pada bulan Safar frekuensi diturunkannya bala bahaya lebih banyak. Untuk menghindari masalah tersebut maka dilakukanlah pembacaan doa bersama kepada Allah SWT dipimpin oleh tokoh agama yang dituakan. Sementara itu di sisi yang berlainan dilakukan praktik ritual buang-buang kepada makhluk halus/leluhur yang dipimpin oleh dukun. Hal ini menunjukkan bahwa upaya pencegahan terjadinya masalah telah dikenal oleh masyarakat lokal. Adapun budaya membantu yang dilakukan pada tradisi roborobo di Sungai Kakap dapat digambarkan sebagai berikut:

Pertama, ritual pencegahan masalah.

Dukun kampung ataupun tokoh agama yang dituakan (penolong/konselor) akan memimpin setelah ditujuk oleh masyarakat setempat untuk memimpin ritual. Selanjutnya dukun dan tokoh agama bertanggung jawab penuh untuk memimpin ritual penolakan bala, sesuai tugas masing-masing. Dalam hal ini dapat dipahami bahwa budaya menolong pada masyarakat lokal dimulai dari penyerahan masyarakat (konseli) untuk meminta bantuan kepada penolong yang diyakini mampu memimpin serta memiliki kapasitas pengetahuan agama dan ritual yang mumpuni. Selanjutnya tanggung jawab penyelesaian masalah diserahkan kepada penolong yang telah ditunjuk.

Kedua, menciptakan ruang untuk bercerita. Di dalam praktinya, tradisi roborobo menciptakan ruang interaksi dan komunikasi akrab untuk masyarakat setempat saat sesi makan bersama. Prosesi makan bersama dilakukan dengan bersaprah, di mana masyarakat dapat makan sambil membuka cerita, masyarakat yang lain dapat mendengarkan, memberikan masukkan dan menanggapi. Hal ini menunjukkan proses penyelesaian masalah melalui diskusi, tukar pendapat antara satu sama lain. Dalam hal ini setiap masyarakat bisa memberikan pandangan dan tidak terpaku kepada tokoh agama atau dukun yang bertindak sebagai penasihat ataupun penceramah.

Ketiga, memberikan kebebasan bagi masyarakat (konseli) dalam menentukan alternatif penyelsaian masalah. Pada dasarnya dalam tradisi robo-robo terdapat dua kayakinan yang dikemas dalam satu rangkaian tradisi, yaitu pembacaan doa selamat kepada Allah SWT dan ritual adat buang-buang yang ditujukan kepada makhluk halus/leluhur. Dalam praktiknya, masyarakat tidak diintimidasi untuk meyakini satu di antaranya, memilih kedua-duanya, ataupun tidak memilih keduanya. Tradisi robo-robo mengambarkan bahwa keyakinan/spiritualitas masyarakat yang dipengaruhi oleh agama ataupun tradisi leluhur dapat berkembang secara berdampingan di dalam ruang sosial masyarakat di Kecamatan Sungai Kakap. Sementara itu dukun dan tokoh agama yang dipilih masyarakat (konseli) untuk memfasilitasi penyelesaian masalah tidak memiliki kapasitas meminta masyarakat memilih satu di antaranya. Sehingga dapat diperoleh gambaran bahwa masyarakat memiliki kebebasan dalam memilih alternatif penyelesaian masalah yang ingin ditempuh tanpa intervensi dari penolong. Hal ini senada dengan hakikat konselor dalat konseling konvensional, bahwa konselor merupakan fasilitator perubahan, tapi tidak memiliki kapasitas untuk menentukan kehidupan konselinya (Laela, 2017:45).

\section{Hubungan Membantu di dalam Tradisi Robo'-robo}

Tuntunan budaya konseling di negara barat pada umumnya konselor berperan sebagai fasilitator yang lebih pasif dalam penyelesaian masalah, sementara konseli diyakini memiliki kemampuan untuk meyelesaikan beragam problem yang dialaminya (Yeh, Hunter, Madan-bahel, Chiang, \& Arora, 2004). Sementara itu di sisi yang berlainan masyakat di Kecamatan Sungai Kakap tidak familiar dengan proses 
konseling melainkan lebih cendrung pada praktik perdukukan dan praktik keagamaan. Hubungan membantu yang terdapat di dalam tradisi robo-robo sangat erat kaitannya dengan spiritualitas (keyakinan) yang berkembang dalam kehidupan masyarakat.

Di dalam praktik perdukunan penolong, dukun atau orang pintar cendrung mengambil peran yang lebih dominan dalam penyelesaian masalah. di mana dalam persfektif ini didasarkan bahwa kendali penyelesaian masalah berada di luar kapapasitas konseli. Mereka membutuhkan media (dukun) untuk menyelesaikan permasalahan tersebut. Oleh karena itu, para dukun umumnya memikul tanggung jawab total untuk kesembuhan orang yang meminta pertolongan. Posisi demikian juga ditempati oleh tokoh agama. Di mana orang yang meminta bantuan akan akan diberikan nasihat keagamaan dan di arahkan untuk ritual kegamaan/amalan berdasarkan petunjuk ustad/kiyai (guru spiritualnya).

Pada umumnya masyarakat, ketika datang kepada penolong maka maindset nya adalah mesalah mereka akan diselesaikan oleh penolong. Masyarakat berharap akan menemukan jalan keluar di dari petunjuk dan pandangan orang yang memberikan pertolongan. Dengan cara berpikir demikian masyarakat menjadi pasrah. Situasi demikian tidak diharapkan di dalam proses konseling karena konseli diharapkan lebih aktif dalam mencari alternatif penyelesaian masalah. Konseling sebagai proses edukasi berupaya memfasilitasi konseli untuk mencegah dan mengatasi masalahnya secara mandiri jika terjadi dikemudian hari.

Menanggapi bagaimana maindset masyarakat dalam hubungan membantu, maka dapat dipahami bahwa implementasi konseling pada masyarakat di Kecamatan Sungai Kakap perlu mempertimbangkan proses penyelesian masalah dan kapasitas konselor. Ada pun proses penyelesaian masalah yang disenangi masyarakat Sungai Kakap adalah berlangsung dengan efisien, tidak bertele-tele, solutif, dan mampu menampilkan perubahan dalam waktu singkat. Sementara itu konselor dituntut untuk bijaksana, berilmu, dan berkeyakinan (spiritual). Pada dasarnya masyarakat memandang konselor (orang yang memberikan bantuan) sebagai seorang yang memiliki kapasitas untuk menyelesaikan permasalahan melalui pengetahuan dan kebijaksanaan yang diikuti oleh kualitas spiritualitas. Hal ini senada dengan hasil penelitian yang dilakukan oleh Gallup pada tahun 1992, yaitu 60\% masyarakat menyukai helper/konselor yang memegang nilai-nilai keyakinan dan spiritual (Basit, 2017: 5).

Masyarakat Sungai Kakap berorientasi pada suatu hubungan. Apabila satu hubungan berjalan dengan baik serta mampu mengatasi permasalahannya, maka akan menimbulkan kepercayaan bahwa konselor bisa diandalkan. Dengan demikian mereka akan suka rela datang kembali untuk melanjutkan proses konseling. Mulanya konselor dituntut untuk berperan aktif dalam menyelesaikan permasalahan, hubungan setara baru dapat dibangun setelah konseli mulai terlibat.

\section{Karakteristik Spiritualitas Masyarakat Sungai Kakap}

Berdasarkan hasil analisis data yang telah diperoleh melalui observasi dan wawancara kemudian ditafsirkan dengan teori karakteristik spiritualitas adalah sebagai berikut:

\section{Hubungan dengan diri sendiri}

Pengetahuan masyarakat terhadap dirinya sendiri yang tergambar melalui pelaksanaan tradisi robo-robo adalah sebagai manusia yang membutuhkan bantuan penciptanya. Masyarakat menyadari bahwa di dalam proses kehidupan ada kekuatan yang maha mengatur, baik kebahagiaan ataupun kesedihan. Oleh karena itu masyarakat Sungai Kakap secara berkala melaksanakan tradisi robo-robo sebagai salah satu bentuk permohohan kepada pencipta-Nya agar dijauhkan dari musibah. Praktik ritual adat yang dilakukan merupakan satu ikhtiar untuk mendapatkan ketenangan, keselamatan serta ketentraman di dalam hidup.

\section{Hubungan dengan alam harmonis}

Hubungan harmonis dengan alam tergambarkan melalui tempat pelaksanaan tradisi robo-robo, di mana ritual adat dilakukan di tempat terbuka, yaitu di lapangan/di luar rumah dan di laut/sungai. Hal ini menampilkan bahwa alam memberikan ruang kehidupan, interaksi dan komunikasi 
antara makhluk. Sebelum pembacaan doa dimulai masyarakat akan duduk bersaf, saling berhadap-hadapan. Di tengah saf telah dijejerkan ketupat serta lauk-pauk yang disediakan oleh masyarakat.

\section{Hubungan dengan orang lain}

Pelaksanaan tradisi robo-robo disejumlah wilayah di Kalimantan Barat dilaksanakan sebagai satu kebudayaan dan tradisi warisan leluhur. Oleh karena itu, di wilayah Kabupaten Kubu Raya pelaksanaan tradisi pembacaan doa tolak bala juga dilakukan di instansi pendidikan, dari Sekolah Dasar (SD)Sekolah Menengah Atas (SMA).

Praktik pekasanaan tradisi robo-robo dilakukan oleh suku Melayu dan Bugis. Akan tetapi, sejumlah pendatang seperti Jawa dan Madura kerap kali ikut terlibat. Dimulai sekadar meramaikan perayaan di Sungai Kakap hingga ikut membuat ketupat untuk dibaca dalam perayaan bersama warga kampung setempat. Hal ini menunjukkan bahwa di antara keberagaman suku dan kebudayaan, masyarakat memegang nilai dan norma soial. Walaupun memiliki perbedaan identitas secara suku, masyarakat di Sungai Kakap memiliki nilai-nilai yang menjadi norma tidak tertulis untuk dianut dalam sistem kemasyarakatan. Adapun nilai yang dianut masyarakat dilihat dari perayaan robo-robo adalah sebagai berikut;

1. Nilai kebersamaan

Nilai kebersamaan pada masyarakat dapat tumbuh dan berkembang dari prosesi makan bersama dengan cara bersaprah di jalan raya atau di lapangan. Di mana masyakat akan duduk berhadapan memakan ketupat yang mereka siapkan di atas tanah.

2. Nilai berbagi dan menghormati

Nilai saling menghargai dan menghormati di dalam pratik pelaksanaan tradisi roborobo dapat dilihat dalam antusias masyarakat. Pada dasarnya tradisi tersebut dilaksanakan oleh masyarakat Melayu Bugis, akan tetapi seiring perkembangan waktu dapat ditemui masyarakat non Melayu Bugis turut membuat ketupat dan mengikuti tradisi pembacaan doa tolak bala. Selain itu, tradisi ini dilaksanakan di sekolahsekolah di wilayah Kecamatan Sungai Kakap. Sebagai mana masyarakat yang membawa ketupat beserta lauk-pauk ke lapangan, anak-anak juga membawa makanan tersebut kesekolah untuk dibacakan doa tolak bala dan makan bersama di lapangan sekolah. Anak-anak diajarkan untuk berbagi apa yang mereka miliki dan sebagian yang lain diajarkan untuk menghargai tradisi yang berkembang di lingkungan tempat tinggalnya, walau di keluarganya tidak turut melaksanakan tradisi.

3. Nilai kekeluargaan

Ketika makan bersama, masyarakat akan memakan ketupat dan lauk yang telah dibawa oleh setiap rumah. Saat prosesi makan berlangsung terjadi perbincangan, bercerita dan saling bercanda. Hal ini menciptakan keakraban anatar masyarakat.

Berdasarkan hasil hasil analisis data yang telah dilakukan bahwa masayarakat di kecamatan Sungai Kakap di tengah keberagamannya memiliki nilai-nilai yang harus dihargai dan ditaati oleh setiap masyarakat, yakni nilai kebersamaan, nilai ramah tamah, nilai saling berbagi dan menghargai, serta nilai kekeluargaan. Ini menjunjukkan satu sistem masyarakat plural, di mana di tengah perbedaan terdapat satu hukum yang mengatur untuk dianut bersama. Melalui pemahaman nilai yang berkembang di tengah masyarakat, maka nilai tersebut secara tidak langsung akan mempengaruhi setiap anggota kelompok masyarakat yang ada di dalamnya kemudian melekat sebagai identitas pribadi (Yusriadi, 2015:7), yakni sebagai pribadi yang bisa menghargai, senang berbagi, memilki rasa kekeluargaan. Hal ini sejalan dengan yang dikemukakan oleh McCormick bahwa karakteristik seorang akan dipengaruhi latar belakang budaya dan wilayah tempat tinggal (McCormick, 1998).

\section{Hubugan dengan ketuhanan}

Esensi dari pelaksanaan tradisi roborobo adalah memanjatkan doa untuk mendapatkan keselamatan dan menolak bala. Dalam kajian ini peneliti memberikan pertanyaan kepada 25 masyarakat di Kecamatan Sungai Kakap yang dipilih secara acak. Hasil wawancara tersebut menunujukkan bahwa ada perbedaan dalam pemaknaan masyarakat terhadap tradisi robo'robo'. Sehingga dapat diklasifikasikan kedalam tiga kelompok yakni; 
1. Masyarakat yang meyakini Allah SWT dan tidak mau terlibat dalam perayaan kebudayaan robo-robo. Masyarakat yang berada dalam katagori ini umumnya tergabung dalam satu kelompok pengajian yang menolak keras kebudayaan yang dianggap menjurus pada penyimpangan beragama. Mereka tidak mengikuti aktifitas masyarakat akan tetatapi tidak mengusik keberlangsungan pelaksanaan ritual adat.

2. Masyarakat yang percaya kepada Allah SWT, mengikuti tradisi robo-robo sebagai satu kebudayaan semata, mereka biasa ikut terlibat dalam perayaan tapi tidak memiliki keyakinan kepada kekuasaan roh leluhur yang mampu mendatangkan kesensaraan. Umumnya masyarakat dalam katagori ini adalah generasi muda dan masyarakat yang berpendidikan, mereka tidak membeda-bedakan orang lain berdasarkan keyakinan.

3. Masyarakat yang memiliki kepercayaan kepada Allah SWT sementara di sisi yang berlainan juga memiliki kepercayaan kepada kekuasaan jin, penunggu, atau roh leluhur yang mampu memberikan nasib baik dan buruk. Masyarakat yang berada dalam katagori ini adalah mereka yang hidup, tinggal dan dibesarkan dengan doktrin demikian dan umumnya memiliki pengalaman spiritual yang berkaitan dengan kegaiban roh leluhur yang dianggap mampu merubah situasi, dari baik menjadi buruk atau sebaliknya. Misalnya menderita sakit berkepanjangan ketika melaknasakan ritual adat tertentu, mereka kembali pulih.

Demikian gambaran spiritualitas (keyakinan) masyarakat di Kecamatan Sungai Kakap yang diidentifikasi melalui tradisi robo-robo. Hal ini dapat menjadi pertimbangan sarjana konseling dalam menyusun strategi pemberian bantuan untuk masyarakat setempat.

Implementasi spiritualitas masyarakat di dalam proses konseling dapat dilakukan dengan berupaya menyesuaikan pendekatan konseling. Sebagaimana hasil analis terhadap tradisi robo-robo bahwa spiritualitas mengambil peran penting dalam proses penyelesaian masalah. Sarjana konseling dapat melibatkan unsur-unsur spiritualitas dan kebudayaan yang tumbuh dan berkembang di dalam ruang sosial masyarakat Sungai Kakap dengan tidak menepikan teknik, konsep, dan tujuan dari proses konseling yang telah berkembang di negara Barat. Teknik yang telah berkembang di Barat dapat dititik beratkan pada untuk menangani emosi, kognitif, kemudian disempurnakan dengan penguatan sisi spiritualitas konseli (Sipon \& $\mathrm{Hj}, 2015)$.

\section{Kesimpulan}

Nilai dan spiritualitas mengambil peran yang sangat penting dalam proses konseling. Masyarakat di Kecamatan Sungai Kakap di lihat dari tradisi robo-robo memiliki karakteristik hubungan membantu antara pemberi bantuan (konselor) dengan orang yang membutuhkan bantuan (konseli), yakni konselor dituntut untuk bijak sana, berilmu, dan memiliki kualitas spiritual. Adapun proses penyelesaian masalah yang disenangi masalah, yaitu efiesien, tidak bertele-tele, solutif dan mampu menampilkan perubahan. Sementara itu budaya membantu dalam tradisi robo-robo adalah kesukarelaan masyarakat dalam menunjuk penolong. Kedua, adanya ruang komunikasi dan tidak ada intervensi dalam penentuan alternatif penyelesian masalah.

Apabila dilihat dari karakteristik spiritualitas masyarakat di Kecamatan Sungai Kakap melalui tadisi robo-robo, aka diperoleh gambaran bahwa: 1) masyarakat menyadari kebutuhan akan pertolongan sang penguasa. 2) masyarakat dekat dengan alam dan lingkungan tempat tinggal. 3) masyarakat memiliki keeratan hubungan antar sesama, nilai-nilai sosial kemasyarakatan seperti nilai kebersamaan, nilai berbagi dan menghormati, serta nilai kekeluargaan. 4) Hubungan dengan ketuhanan, dalam tradisi robo-robo diperoleh tiga gambaran dalam keyakinan masyarakat, pertama, memiliki keyakinan kepada Allah SWT, dan tidak mau melibatkan diri pada tradisi robo-robo. Kedua, memiliki keyakinan kepada Allah SWT, terlibat dalam perayaan kebudayaan sebagai upaya pelestarian. Ketiga, Mereka beragama memilki keyakinan kepada Allah SWT akan tetapi di sisi yang beerlainan juga memiliki keyakinan terhadap kegaiban yang lain (makhluk halus/roh leluhur). 


\section{Daftar Pustaka}

Arifin, S. (2013). Konseling Indigenous Berbasis Pesantren: Teknik Pengubahan Tingkah Laku Kalangan Pesantren. Jurnal Lisan Al-Hal: 7(1), 95-119.

Basit, A. (2017). Bimbingan dan Konseling Islam. Depok: Kencana.

Baharudin. (2021). Wawancara

Chong, Florence Hiu-ha. (2018). "Indigenous Counseling in the Chinese Cultural Context: Experience Transformed Model Indigenous no. January 2002.

Geldart, Kathryn \& Geldard, David. (2015). Membantu Memecahkan Masalah Orang Lain dengan Teknik Konseling. terj. Agug Prihantoro. Yogyakarta: Pustaka Pelajar.

Gunando, Prevesti. C. A., Wahyuni, F., \& Kiswantoro, A. (2017). Psikologi Spiritualitas dalam Konseling. 3(1), 114127.

Hamid, Achir Yani S. (2008). Bunga Rampai Asuhan Keperawatan Kesehatan Jiwa. Jakarta: Penerbit Buku Kedokteran EGC.

Hidayah, R. N., Apriliana, N., \& Triningtyas, D. A. (2017). Indigenous Counseling Sebagai Alternatif. Proseding SNBK: 1(1), 154-158.

Imaduddin, Aam. (2017). "Spiritualitas Dalam Konteks Konseling" 1: 1-8.

Induk Tuwo. (2021). Wawancara.

Laela, F. N. (2017). Bimbingan Konseling Sosial. Surabaya: UINSA Press.

Lubis, S. A. (2011). Konseling Islami dan Kesehatan Mental.Bandung: Cipta Pustaka Media Perintis.

Mahmud. (2018). indigenous Konseling Gusjigang dalam Pemikiran Kearifan Lokal Sunan Kudus. Konseling Edukasi: Journal of Guidance and Counseling. Vol. 2, no (1): 117-131.

Marhamah, U., Murtadlo, A. \& Awalya. (2015). Indigenous Konseling (Studi Pemikiran Kearifan Lokal Ki Ageng Suryomentaram dalam Kawaruh Jiwa). Jurnal Bimbingan Konseling. 4(2), 100108.
McCormick. (1998). Etnical Considerations in First NATIONS Counselling and Research. canadian. Jurnal Of Counselling. vol. 32 (4). 294-297.

Mohamad, Mardiana, Halimatun Halaliah, and Asnarulkhadi Abu. (2011). "Social and Person-Centered Counseling with Malay Clients : Spirituality as an Indicator of Personal Growth" 30. https://doi.org/10.1016/j.sbspro.2011.10. 411.

Prasasti, S. (2020). Konseling Indigenous dalam Masa New Normal. widya wacana : jurnal ilmiah. 2. 133-139

Prasasti,\& Suci. (2020). Konseling indigenous: mengenali nilai-nilai kearifan lokal pada tradisi sedekah Bumi dalam Budaya Jawa. 14(2), 110-124. https://doi.org/10.30957/Cendekia.v14i2. 626.

Rangka, I. B. (2016). Konseling Indigenous : Rekonstruksi Konseling Di Tengah Keragaman Budaya . 19-20.

Rofiqi, M Aris. 2019. "Relevansi Agama Dan Spiritual Dalam Konseling” 1, no. 2: 6171.

Sari, Permata, and Siti Zahra Bulantika. 2019. "Konseling Indigenous Berbasis Tata Nilai Budaya Lampung ' Piil Pesenggiri' Dalam Pembentukan” 9, no. 2: 190-99.

Saripaini \& Yusriadi. (2016). Identitas Orang Bugis di Dabong, Kalimantan Barat. Jurnal Khatulistiwa. Vol. 6, no 2: 170182.

Saripaini. 2016. Masyarakat Bugis di Punggur. Pontianak: STAIN Pontianak Press.

Sarwono, R Budi. 2018. "Menggugah Semangat Indigenous Dalam Praksis Konseling Di Indonesia” 2, no. 1: 1-8.

Sipon, Sapora, and Amin Hj. 2015. "Managing Spirituality in Solving Family Issues." Procedia - Social and Behavioral Sciences 185: 214-17. https://doi.org/10.1016/j.sbspro.2015.03. 450.

Suwarni \& Ulfah, M. (2017). Internalisasi Tradisi Robo-robo Sebagai Sumber Sejarah Lokal di Kelas X SMA Negeri 2 Kabupaten Mempawah. Sosial Horizon: 
Jurnal Pendidikan Sosial. Vol. 4, No. 2: 188-197.

Wahidin. (2017). Spiritualitas Dan Happiness

Pada Remaja Akhir Serta Implikasinya

Dalam Layanan Bimbingan Dan Konseling. Inovetive Counselling. 1 (1).57-66.

Wibowo, A, \& Mudaim. (2018). Kajian Unsur Budaya Lampung dan Implikasinya Pada Pelaksanaan Konseling Lintas Budaya. Jurnal Fokus Konseling: 4(2), 224-230. https://doi.org/10.26638/jfk.504.2099.

Willemse, Suzan, Wim Smeets, Evert Van Leeuwen, and Trijnie Nielen-rosier. 2020. "Spiritual Care in the Intensive Care Unit : An Integrative Literature Research." Journal of Critical Care 57: 55-78. https://doi.org/10.1016/j.jcrc.2020.01.02 6.
Yeh, Christine J, Carla D Hunter, Anvita Madan-bahel, Lillian Chiang, and Agnes $\mathrm{K}$ Arora. 2004. "Indigenous and Interdependent Perspectives of Healing: Implications for Counseling and Research" 82: 410-19.

Yusriadi. (2015) Orang Bugis di Sungai Kakap Kalimantan Barat. Pontianak: IAIN Pontianak Press. 